\title{
RADIOPROTECTIVE EFFECTS OF HIGH PROTEIN DIET, VITAMINS C AND E ON LIVER ACTIVITY, KIDNEY FUNCTION AND SERUM APOPTOSIS RATES OF IRRADIATED RATS
}

Shallan, A.M. ; Hanaa F. M. Ali ${ }^{1}$; A.M. Ahmed ${ }^{2}$ and Mona M.A. Ghoneim ${ }^{2}$

1: Department of Biochemistry, Faculty of Agriculture, Cairo University.

2: Biochemistry Department, Atomic Energy Authority, Giza.

e-mail: magdyshallan@hotmail.com

\begin{abstract}
This study designed to investigate the role of high protein diet, vitamin $\mathrm{C}$ and vitamin $\mathrm{E}$ as radioprotectors in rats followed exposure to 7 Gy whole body gamma irradiation. 120 male albino rats were divided into six equal groups of 20 rats each: control, irradiated, high protein $(P)$, vitamin $C$, vitamin $E$ and combination $C+E+P$ supplemented groups. The variation in activities of alanine aminotransferase (ALT) and aspartate aminotransferase (AST), urea and creatinine concentrations were estimated for all groups. Serum apoptosis detection was carried out according to the Enzyme-Linked ImmunoSorbent Assay technique (ELISA). In the irradiated group, an increase in serum ALT and AST activities, urea and creatinine concentrations and apoptosis rate were observed, whereas in almost irradiation treated groups, the reverse was occurred. Based on these biochemical observations, it was concluded that high protein, vitamin $\mathrm{C}$ and vitamin $\mathrm{E}$ treatment exerts a protective effect against irradiation damage, especially in serum AST, creatinine and apoptosis.

Keyword: Radioprotectors, vitamin C, vitamin E, soybean protein, Liver Activity, Kidney Function and Serum Apoptosis
\end{abstract}

\section{INTRODUCTION}

Military personnel and civilian population are at risk of exposure to radiation from nuclear or radiological attack. The deleterious effects of ionizing radiation in biological systems are mainly mediated through the generation of oxygen-derived intermediates such as hydroxyl radical, super oxide radical and hydrogen peroxide causing various types of tissue damage due to successive free radical reactions (Fang, 1991).

Oxygen free radicals are highly reactive chemical species generated in biological systems during numerous physiological and pathophysiological processes (Marton et al., 2001). In physiological circumstances, they play a role in cellular metabolism and cellular defense systems. Meanwhile, in large amounts they are highly toxic for tissues and cells because they can oxidatively modify and damage various biological systems (Hogg, 1998). When damage is caused at the molecular level, it is usually irreversible and leads to cell death.

Radiation exposure of mammals is known to induce pronounced changes in the metabolism of biological tissues. It is known that liver and kidney are involved in these changes.

Liver is a central organ for many physiological and biochemical processes necessary for the maintenance of life. Morphological alterations 
that occur in liver affect many metabolic processes in organism. Peroxide formation induced by ionizing radiation result in the release of some enzymes by interacting with cellular structure and function (Yanardag et al., 2001). Thus, the serum activities of cellular enzymes such as transaminases do increase. It has been reported that radiation results increased urea and creatinine concentrations of serum as an evidence for marked impairment of kidney function (Cadenas and Cadenas, 2002).

Irradiation can induce both DNA and membrane damage (Szumiel, 1994; Haimovitz-Friedman, 1998; and Szumiel, 1998). In many cases, irradiation-induced cell death has been identified as apoptosis (Yanagihara et al., 1995; Barlow et al., 1997; Gobbel et al., 1998a, Haimovitz-Friedman, 1998).

Apoptosis is defined as programmed cell death represents a universal mechanism (pathway) by which undesirable, unhealthy, harmful, unwanted or excess cells are eliminated during the development and maturation of most organisms, tissue homeostasis and in response to injury (Alici et al., 2000; Yan et al., 2000 and Tchell et al., 2001). In the same context, Guido et al. (1995) reported that cell death is involved in the removal of superfluous and damaged cells in most organ system. It has been shown that many kinds of cells including thymocytes, circulating lymphocytes,(Cui et al., 1999) and resident peritoneal macrophages (Kubota et al., 2004) undergo apoptosis after exposure to clinically relevant doses of ionizing radiation. Apoptosis could be characterized by several biochemical and morphological changes, including DNA fragmentation, impairment of ATP synthesis, chromatin, endoplasmic reticulum-derived vacuoles and the "bubbling" of cytoplasm. The condensed nucleus is fragmented into membrane-enclosed "apoptotic bodies". The final biochemical characteristic of apoptosis is nuclear DNA fragmentation into oligonucleosomal subunits, that can be recognized from random cleavage observed in cells undergoing necrosis.

There are several methods defense mechanisms that protect living organisms against free radicals. Radioprotectors could be identified as chemical compounds capable of ameliorating the biological influences of ionizing radiation when administered before radiation exposure. The efficiency of these radioprotectors is greatly dependent on their chemical properties, period of treatment and the post irradiation time elapsing after radioprotectors application (Monig et al., 1990).

Antioxidants such as vitamins $\mathrm{E}$ and $\mathrm{C}$ are substances that when present in low concentrations relative to the oxidizable substrate significantly delay or reduce oxidation of the substrate, or they are substances that protect other chemicals of the body from damaging oxidation reactions by reacting with free radicals and other reactive oxygen species within the body, hence hindering the process of oxidation. During this reaction the antioxidant sacrifices itself by becoming oxidized. However, antioxidant supply is not unlimited as one antioxidant molecule can only react with a single free radical. Therefore, there is a constant need to replenish antioxidant resources, whether endogenously or through supplementation (Halliwell and Gutteridge, 1995). 
Soybean seed is consider as one of the best sources of plant protein because the quality of amino acids in soy protein is approximately equivalent to animal protein in spite of its deficiency in methionine (Morita et al., 1997 and Anderson et al., 1999). Also, soybean supplementation has an antioxidant activity which prevents the generation of oxidative stress (Abdullaev et al., 2002).

Because radioactive materials in the environment continuously irradiate us with low dose rate, we should construct an appropriate experimental system to evaluate their biological effects.

Thus the present study was aimed to study the radioprotective effects of vitamins $C$ and $E$ and high soybean protein diet and combination of vitamins $C$ and $E$ and high soybean protein diet on liver and kidney functions and serum apoptosis rate of irradiated rats.

\section{MATERIALS AND METHODS}

\section{Cheminals and Reagents:}

Vitamin $C$ and vitamin $E$ ( $\alpha$-Tocopherol) were purchased from Adwin Egypt Company and ACF Chemical Company, Holland, respectively . Soybean protein were supplied from Food Technology Institute, Agricultural Research Center, Giza, Egypt. The determination of serum ALT and AST were measured using commercial kit supplied from BioMérieux Vitek, Inc., USA. The colorimetric determination of serum urea was measured using commercial kit supplied from Human Laboratory, Wiesbaden, Germany. The determination of serum Creatinine was measured using commercial kit supplied from Stanbio Laboratory, Inc. San Antonio, Texas, USA. Cell death detection (Apoptosis) was measured using a commercial kit derived from Roche Diagnostics Gmbh, Roche Molecular Biochemicals, Mannheim, Germany.

\section{Irradiation Source :}

The irradiation source used in this study is Cobalt -60 (gamma -cell 220),Atomic Energy of Canada limited, installed at the Middle Eastern Regional Radioisotopes Center for the Arab Countries, Dokki, Cairo .

\section{Animal Diet:}

The balance diet consists of $60 \%$ corn, $20 \%$ soybean, $10 \%$ growth additives, $5 \%$ wheat bran and fibers, $2.75 \%$ molas, $1.5 \%$ powdered bone, $0.5 \%$ table salt and $0.25 \%$ vitamins, supplied from National Research Centre, Giza.

Highly protein diet consists of the same composition of the balanced diet with the excess of protein as soybean to reach $30 \%$.

\section{Experimental Design:}

One hundred and twenty male albino Sprake Dawley rats (body weight from 120 to 140 grams) were obtained from the Animal House, at the National Research Centre, Dokki, Giza. They were randomly divided into six groups of twenty animal each and housed in a wire - bottom cages with 


\section{Shallan, A.M. et al.}

controlled ambient temperature $\left(26-32^{\circ} \mathrm{C}\right)$ and the mean relative humidity was $60 \%$ (range from 50 to 70 ), at the Animal House, Radioisotopes Department, Atomic Energy Authority, Giza. All animals were freely fed on standard rodent pellets and clean water offered ad-libitum throughout the adaptation period.

Group I: rats received balanced diet for three weeks, served as control.

The other animals were exposed to whole body gamma irradiation (7 Gy) and divided into:

Group II: rats received balanced diet for two weeks, served as irradiation control.

Group III: rats fed daily for one week before $y$ - irradiation and two weeks post $y$ irradiation exposure on highly protein diet.

Group IV: Animal fed on balanced diet and received vitamin C daily at a dose level of $100 \mathrm{mg} / \mathrm{kg}$ body weight orally via stomach tube for one week before $\mathrm{Y}$-irradiation and for two weeks post $\mathrm{y}$-irradiation exposure.

Group V: Animal fed on balanced diet and received vitamin $\mathrm{E}$ daily at a dose level of $50 \mathrm{mg} / \mathrm{kg}$ body weight orally via stomach tube for one week before $\gamma$-irradiation and two weeks post $\gamma$-irradiation exposure.

Group VI: combination group : Animals fed on highly protein diet, and treated with vitamin $C$ and vitamin $E$ at the same dose level as in group IV, $\mathrm{V}$, respectively, orally via stomach tube for one week before $\gamma$ irradiation and continued for two weeks post $y$-irradiation .

\section{Blood Sampling:}

Blood samples were withdrawn from optical nerve plexus at the end of every week once for three weeks from the beginning of the study. The blood samples were collected in plane test tube, then kept at $37^{\circ} \mathrm{C}$ till coagulation and then centrifuged for 15 minutes at $3000 \mathrm{rpm}$. The sera samples were thereafter separated and stored at $-20^{\circ} \mathrm{C}$ till analysis.

\section{Biochemical Investigation:}

The following are known spectrophotometric biochemical determinations. Serum alanine aminotransferase (ALT) and aspartate aminotransferase (AST) activities were measured according to a procedure by Thefeld, (1974). Serum urea was determined by enzymatic colorimetric method described by Fawcett and Scott (1960). Determination of serum creatinine was carried out according to the method of Cook , (1975).

Serum apoptosis detection was carried out according to the Enzyme Linked ImmunoSorbent Assay technique (ELISA) established by method of Gougen and Montagnier (1993).

\section{Statistical Analysis:}

All values were presented as mean \pm S.D. significant differences among the various experimental and control groups were established by means of the student's t-test using Microsoft excel for Office 2003. 


\section{RESULTS AND DISCUSSION}

\section{Liver Function: \\ Serum ALT and AST Activities:}

Table (1) presents the results for serum ALT activity in the experimental groups at three time intervals.

At the end of pre- $\mathrm{Y}$-irradiation week, no differences were observed between control and all supplemented groups. In comparison with control at the end of $1^{\text {st }}$ and $2^{\text {nd }}$ weeks post $y$-irradiation, a high significant increase of the serum ALT activity was observed for the irradiated group. This result is in agreement with Abdel Gawad and Amer (2001), Ramadan et al. (2001) and Abdel Gawad et al. (2003). In the groups receiving vit. C, vit. E and combination (vit. $C+$ vit. $E+P$ ), at the end of $1^{\text {st }}$ week post $Y$-irradiation, the same finding as in irradiated group was found with clear modulation in vit. $\mathrm{C}$ group at the end of $2^{\text {nd }}$ week post $y$-irradiation.

Table(1): Serum ALT activity(U/L) of the experimental groups within the time intervals.

\begin{tabular}{|c|c|c|c|c|c|c|}
\hline Group & Control & Irradiated & Protein & Vitamin C & Vitamin E & $E+C+P$ \\
\hline \multicolumn{7}{|c|}{ Pre-irradiation } \\
\hline Mean \pm S.D. & $23.4 \pm 2.30$ & & $25 \pm 1.87$ & $25.4 \pm 3.65$ & $23.2 \pm 1.79$ & $26.8 \pm 2.86$ \\
\hline Change \% & & & 6.8 & 8.6 & -0.9 & 14.5 \\
\hline \multicolumn{7}{|c|}{$1^{\text {st }}$ week post-irradiation } \\
\hline hean \pm S.D. & $21.2 \pm 2.86$ & $29.6^{* *} \pm 4.34$ & $15.8^{* * c} \pm 0.84$ & $34.6^{* * *} \pm 4.34$ & $34.2^{* * *} \pm 4.03$ & $33.2^{* * *} \pm 3.70$ \\
\hline Change \% & & 39.6 & -25.5 & 63.2 & 61.3 & 56.6 \\
\hline \multicolumn{7}{|c|}{$2^{\text {nd }}$ week post-irradiation } \\
\hline Mean \pm S.D. & $20.4 \pm 2.61$ & $34.7^{* * *} \pm 3.12$ & $20.8^{c} \pm 2.28$ & $28^{* * b} \pm 3.16$ & $35^{* * *} \pm 3.67$ & $36^{* *+*} \pm 4.06$ \\
\hline Change \% & & 70.1 & 2 & 37.3 & 71.6 & 76.5 \\
\hline
\end{tabular}

* Slightly significant to control, ${ }^{* *}$ Moderately significant to control, ${ }^{* * *}$ Highly significant to control.

a, Slightly significant to irradiated group; b, Moderately significant to irradiated group; c, Highly significant to irradiated group.

On the other hand, when compared to control, an insignificant effect was observed in serum ALT activity of high protein supplemented diet group but significant change compared to irradiated group. That means that serum ALT activity of high protein supplemented diet group was not affected by $\mathrm{Y}$ irradiation, whereas had a protective effect within the experiment period against radiation. 
Table (2): Serum AST activity (U/L) of the experimental groups within the time intervals.

\begin{tabular}{|c|c|c|c|c|c|c|}
\hline Group & Control & Irradiated & Protein & itamin C & litamin $\mathrm{E}$ & $\mathrm{E}+\mathrm{C}+\mathrm{P}$ \\
\hline \multicolumn{7}{|c|}{ Pre-irradiation } \\
\hline lean \pm S.D. & $.73 .76 \pm 5.48$ & & $74.88 \pm 4.02$ & $71.6 \pm 5.26$ & $56.6^{* *} \pm 5.46$ & $55.08^{* * *} \pm 3.39$ \\
\hline Change \% & & & 1.5 & -2.9 & -23.3 & -25.3 \\
\hline \multicolumn{7}{|c|}{$1^{\text {st }}$ week post-irradiation } \\
\hline lean \pm S.D. & $.73 .6 \pm 9.32$ & $90.6^{*} \pm 8.53$ & $75.8^{a} \pm 7.69$ & $73.2^{b} \pm 5.81$ & $58.2^{* \mathrm{c}} \pm 8.47$ & $63.8^{\mathrm{c}} \pm 6.50$ \\
\hline Change \% & & 23.1 & 3 & -0.5 & -20.9 & -13.3 \\
\hline \multicolumn{7}{|c|}{$2^{\text {nd }}$ week post-Irradiation } \\
\hline lean \pm S.D. & $72 \pm 8.80$ & $127^{* * *} \pm 8.6 \varsigma$ & $106.8^{* *+b} \pm 7.01$ & $91.8^{* * \mathrm{C}} \pm 8.23$ & $82.6^{* c} \pm 3.58$ & $57.6^{* \mathrm{c}} \pm 8.91$ \\
\hline Change \% & & 76.4 & 48.3 & 27.5 & 14.7 & -20 \\
\hline
\end{tabular}

The activity of serum AST for the irradiated group significantly was increased at $1^{\text {st }}$ week post $\gamma$-irradiation compared to control and this increase became more and very highly significant at the end of the $2^{\text {nd }}$ week post $\mathrm{Y}^{-}$ irradiation (Table2). This result is in agreement with Abdel Gawad and Amer (2001), Ramadan et al. (2001) and Abdel Gawad et al. (2003).

When compared to control, an insignificant effect was observed in serum AST activity of the supplemented diet groups at pre- $\gamma$-irradiation week. The same result was observed at the end of $1^{\text {st }}$ week post $Y$-irradiation in spite of exposure these groups to $7 \mathrm{~Gy} \mathrm{Y}$-irradiation. However, at the end of the $2^{\text {nd }}$ week post $\mathrm{Y}$-irradiation, the supplemented diet groups with vit. C, vit. $\mathrm{E}$ and high protein diet had significant increase in the serum AST activity compared to control. In post- $y$-irradiation period, a significant reduction in serum AST activity was observed in all supplemented diet groups compared at that of the irradiated group. It is in agreement with Abdel Gawad et al. (2003), they reported that intraperitoneal injection of $\mathrm{y}$-irradiated rats, at a dose level of 7 Gy, with vit. E caused a significant reduction in serum activity of AST compared to irradiated rats.

The results of the present study revealed that, $\mathrm{Y}$-irradiation increases both serum AST and ALT activity level which mainly due to the release of both enzymes in blood. The increases in the serum activities of these enzymes were directly proportional to the degree of cellular damage (Yanardag et al., 2001). During the post $\mathrm{Y}$-irradiation period, the increment of ALT activity was clearly noticed more rapid than AST activity. This may return to the fact concluded that, in acute hepatic cell injury the level of ALT activity is affected and elevated more than AST activity level. On the other hand, at the end of post $y$-irradiation period, ALT activity was decreased by high protein and vit.C supplementation, while AST activity was decreased for all supplemented diet groups. This decrease may be due to the antioxidant effects which caused preventing the formation of free radicals or to quench their cell damaging effects and protect the cell against lipid peroxidation (Packer, 1991; Jaime, 2002 and lkeda et al., 2004). 


\section{Kidneys Function:}

\section{Serum Urea Concentration:}

At the end of pre-y-irradiation week, vit. $C$ and vit. E supplemented diet groups had no differences compared to control in serum urea concentration. Conversely in both highly protein and combination groups showed highly significant increase in serum urea concentration as given in Table (3).

Table (3): Serum urea concentration $(\mathrm{mg} / \mathrm{dl})$ of the experimental groups within the time intervals.

\begin{tabular}{|c|c|c|c|c|c|c|}
\hline Group & Control & Irradiated & Protein & Vitamin C & Vitamin E & $E+C+P$ \\
\hline \multicolumn{7}{|c|}{ Pre-irradiation } \\
\hline \multicolumn{2}{|c|}{ Mean \pm S.D $42.8 \pm 2.16$} & & $2.54^{* * *} \pm 0.95$ & $45.3 \pm 4.78$ & \multicolumn{2}{|c|}{$42.5 \pm 2.0355 .02^{* * * *} \pm 1.58$} \\
\hline Change $\%$ & & & 22.8 & 5.9 & -0.7 & 28.6 \\
\hline \multicolumn{7}{|c|}{$1^{\text {st }}$ week post-irradiation } \\
\hline \multicolumn{2}{|c|}{ Mean \pm S.D. $5.52 \pm 4.34$} & $67.58^{* * *} \pm 6.21$ & $0.78^{* * * a} \pm 6.29$ & $3.84^{c} \pm 2.02$ & \multicolumn{2}{|c|}{$6.46^{\mathrm{b}} \pm 8.62 \$ 4.14^{*+*} \pm 5.46$} \\
\hline Change \% & & 48.5 & 77.5 & -3.7 & 2.1 & 40.9 \\
\hline \multicolumn{7}{|c|}{$2^{\text {nd }}$ week post-irradiation } \\
\hline \multicolumn{2}{|c|}{ Mean \pm S.D $43.6 \pm 4.44$} & $50.94^{*} \pm 4.57$ & $1.74^{* * *} \mathrm{c} \pm 11.55$ & $5.51^{* * *} \pm 5.29$ & $47.98 \pm 2.74$ & $76.9^{* * * c} \pm 5.73$ \\
\hline Change \% & & 16.8 & 110.4 & 73.2 & 10.1 & 76.4 \\
\hline
\end{tabular}

a, Slightly significant to irradiated group; b, Moderately significant to irradiated group; c, Highly significant to irradiated group.

At the end of two weeks post $\mathrm{y}$-irradiation, the levels of urea of irradiated group were clearly higher than control level, also highly protein diet and combination diet groups gave the same results. In the vit. E supplemented diet group, the level of urea had no significant change compared to control through the two weeks post $y$-irradiation. In contrast, when comparing to irradiated group, there was a significant decrease at the end of $1^{\text {st }}$ week post $\gamma$-irradiation. Whereas in vit. C supplemented diet group gave the same results with the vit. $E$ group at $1^{\text {st }}$ week post $\gamma$-irradiation, but at $2^{\text {nd }}$ week post $\mathrm{Y}$-irradiation urea level became higher than that in irradiated group and control.

It is clear that the exposure of rats to $7 \mathrm{~Gy} Y$-irradiation produced renal damage and increased the serum urea concentration. These results come similar to previous investigations obtained by EL-Gabry et al. (2003) and Badr EL-Din (2004). This increase in urea level could be considered as a reflection of deteriorating renal performance (Geraci et al., 1990) due to the ammonia formed by deamination of amino acids in liver, which converted to urea. While in supplemented diet rats with only antioxidant vitamins $\mathrm{E}$ and $\mathrm{C}$, both of vit. $\mathrm{C}$, especially in $1^{\text {st }}$ week post $\mathrm{Y}$-irradiation, and vit. E within experiment period acts as an effective antioxidants of major importance for protection against degenerative processes caused by oxidative stress (Olas and Wachowiez, (2002) and Kanter et al. (2005)).

In vit. C supplemented diet group at $2^{\text {nd }}$ week post $y$-irradiation, the protective effect of vit. $C$ as antioxidant which noticed at $1^{\text {st }}$ week did not 
continue, it could be attributed to the dose of vit. $C$ which used in the present study $(100 \mathrm{mg} / \mathrm{kg} \mathrm{bw})$. This finding could be in agreement with Kanter et al. (2005), they reported that vit. C increases tissue protection against diseases and degenerative processes caused by oxidative stress when they used 500 $\mathrm{mg} / \mathrm{kg}$ bw.

On the other hand, the high increase of urea level at all the experiment period in both highly protein and combination supplemented diet rats may attribute to high protein percentage in the diet of these groups which gave urea as the exogenous end product of protein intake. Protein quality, the proportion of essential amino acids in a food relative to their proportion in proteins undergoing synthesis is, however, of critical importance. Excess amino acids are not stored. Regardless of source, those not immediately incorporated into protein are rapidly degraded (Murray et al., 1993).

\section{Serum Creatinine Concentration:}

As seen in Table (4), serum creatinine level was not altered in all supplemented diet groups compared to control in the period of pre- $\mathrm{y}$ irradiation. The same observation was reported by Cay and Naziroglu (1999) when they studied the effect of vit. E intraperitoneal injection for 5 weeks in serum Creatinine level.

In the irradiated group at the end of the two weeks post $\mathrm{y}$-irradiation, the level of creatinine was clearly higher than the control level. This result is in agreement with EL-Gabry et al. (2003) and Badr EL-Din (2004). The levels of serum creatinine for the two supplemented diet groups with vit. $\mathrm{C}$ and vit. $\mathrm{E}$ were insignificantly different compared to control till the end of the experiment, while they had a significant decrease in creatinine level when compared to the irradiated group at the end of $2^{\text {nd }}$ week post- $y$-irradiation. In high protein group, there was an insignificant difference at the end of $1^{\text {st }}$ week post $y$-irradiation, while at the end of $2^{\text {nd }}$ week post $y$-irradiation the creatinine level was significantly decreased compared to control. This group showed a highly significant reduction effect compared to the irradiated group within the period of post- $\gamma$-irradiation.

Table (4): Serum Creatinine $(\mathrm{mg} / \mathrm{dl})$ concentration of the experimental groups within the time intervals.

\begin{tabular}{|c|c|c|c|c|c|c|}
\hline Group & Control & Irradiated & Protein & Vitamin C & Vitamin E & $\mathrm{E}+\mathrm{C}+\mathrm{P}$ \\
\hline \multicolumn{7}{|l|}{ Pre-irradiation } \\
\hline Mean \pm S.D. & $0.19 \pm 0.02$ & & $0.21 \pm 0.04$ & $0.18 \pm 0.01$ & $0.22 \pm 0.03$ & $0.21 \pm 0.04$ \\
\hline Change \% & & & 7.3 & -5.2 & 14.6 & 7.3 \\
\hline \multicolumn{7}{|c|}{$1^{\text {st }}$ week post-irradiation } \\
\hline Mean \pm S.D. & $0.2 \pm 0.02$ & $0.25^{* *} \pm 0.02$ & $0.19^{c} \pm 0.01$ & $0.23 \pm 0.05$ & $0.21 \pm 0.04$ & $0.30^{* *} \pm 0.05$ \\
\hline Change \% & & 27 & -7 & 13 & 7 & 52 \\
\hline \multicolumn{7}{|c|}{$2^{\text {nd }}$ week post-irradiation } \\
\hline Mean \pm S.D. & $0.2 \pm 0.03$ & $0.30^{* *} \pm 0.05$ & $0.12^{* * c} \pm 0.04$ & $0.23^{a} \pm 0.04$ & $0.22^{\mathrm{a}} \pm 0.04$ & $0.22^{a} \pm 0.04$ \\
\hline Change \% & & 51 & -42 & 13 & 12 & 12 \\
\hline
\end{tabular}

* Slightly significant to control, ${ }^{* \star}$ Moderately significant to control, ${ }^{* \star *}$ Highly significant to control. a, Slightly significant to irradiated group; b, Moderately significant to irradiated group; c, Highly significant to irradiated group. 
The combination diet group at the end of the $1^{\text {st }}$ week post $y$-irradiation had the same trend that noticed in irradiated group, however in the $2^{\text {nd }}$ week post $Y$-irradiation this trend changed to reach the level of the control.

From these results, the exposure of rats to $7 \mathrm{~Gy} \mathrm{y}$-irradiation induced increase creatinine level in serum which serve as an index of renal function impairment (Farag, 1994).

The antioxidant supplementation diet has proven to be beneficial in decreasing the oxidative stress and preventing the renal tissue damage which induced by exposuring to $y$-irradiation. This finding is in agreement with Kanter et al. (2005), they revealed that vit. C treatment reduced serum creatinine elevation which induced as reflect of renal tissue damage and with Cadenas and Cadenas (2002), they reported that vitamins (A, C and E) are ideal antioxidants to increase tissue protection from oxidative stress due to their easy, effective and safe dietary administration in a large range of concentrations without harmful side effects.

\section{Serum Apoptosis:}

Table (5) represents the rates of serum apoptosis of the experimental groups. At the end of pre- $y$-irradiation week, rate of apoptosis of groups which gave supplemented diet with vit. $\mathrm{C}$ and /or vit. $\mathrm{E}$ and combination $(\mathrm{E}+\mathrm{C}+\mathrm{P})$ was decreased significantly compared to control $(61.5 \%, 32.5 \%$ and $42.2 \%$, respectively, $\mathrm{P}<0.001)$. While for the high protein supplemented diet group, the apoptosis rate was near to control.

Table (5): Serum apoptosis rate of the experimental groups within the time intervals.

\begin{tabular}{|c|c|c|c|c|c|c|}
\hline Group & Control & Irradiated & Protein & Vitamin C & Vitamin E & $E+C+P$ \\
\hline \multicolumn{7}{|l|}{ Pre-irradiation } \\
\hline Mean \pm S.D. & $0.03 \pm 0.003$ & & $0.03 \pm 0.01$ & $0.01^{*} \pm 0.002$ & $0.02 \pm 0.0030$ & $0.02 \pm 0.01$ \\
\hline Change \% & & & -3.6 & -61.5 & -32.5 & -42.2 \\
\hline Enrichment factor & & & 0.96 & 0.4 & 0.7 & 0.6 \\
\hline \multicolumn{7}{|c|}{$1^{\text {st }}$ week post-irradiation } \\
\hline Mean \pm S.D. & $0.03 \pm 0.003$ & $0.10^{*} \pm 0.005$ & $0.02 \pm 0.001$ & $0.01 \pm 0.001$ & $0.05 \pm 0.0020$ & $0.05 \pm 0.002$ \\
\hline Change \% & & 197.6 & -56.0 & -63.9 & -53.6 & 37.4 \\
\hline Enrichment factor & & 3 & 0.4 & 0.4 & 1.5 & 1.4 \\
\hline \multicolumn{7}{|c|}{$2^{\text {nd }}$ week post-irradiation } \\
\hline Mean \pm S.D. & $0.03 \pm 0.002$ & $0.05^{*} \pm 0.003$ & $0.02^{*} \pm 0.001$ & $0.01 \pm 0.001$ & $0.01^{*} \pm 0.0010$ & $0.06^{*} \pm 0.002$ \\
\hline Change \% & & 58.3 & -39.3 & -60.7 & -72.0 & 63.1 \\
\hline Enrichment factor & & 1.6 & 0.6 & 0.4 & 0.3 & 1.6 \\
\hline
\end{tabular}


At the end of $1^{\text {st }}$ post $\mathrm{y}$-irradiation week, the irradiated group demonstrated high significant increase compared to control $(197 \%, \mathrm{P}<$ 0.001 ), while in $2^{\text {nd }}$ post $y$-irradiation week this change was lower but still highly significant $(58.3 \%, \mathrm{P}<0.001)$.

Compared to control, apoptosis was highly significant decreased in vitamin $\mathrm{C}$ and high protein diet groups $(63.9 \%$ and $56 \%$, respectively, $\mathrm{P}<0.001)$ at the end of $1^{\text {st }}$ post $\mathrm{y}$-irradiation week while in vitamin $\mathrm{E}$ and combination diet groups, apoptosis rates were increased significantly $(53.6 \%$ and $37.4 \%$, respectively, $\mathrm{P}<0.001$ ).

On the other hand, all supplemented diet groups had lower significantly the rates of apoptosis than irradiated group at the $1^{\text {st }}$ post $\mathrm{\gamma}$-irradiation week.

As seen in Table (5), all supplemented diet groups (vitamin E, C and high protein) reduced rate of apoptosis significantly compared to control group at the end of $2^{\text {nd }}$ of post $y$-irradiation $(72 \%, 60.7 \%$ and $39.3 \%$, respectively), except the combination diet group increased the apoptosis rate significantly $(63.1 \%, P<0.001)$.

At the end of $2^{\text {nd }}$ post $\mathrm{y}$-irradiation, all supplemented diet groups reduced rate of apoptosis significantly than irradiated group through the period of post $y$-irradiation, except the combination diet group had almost the apoptosis rate in irradiated group .

$\mathrm{Y}$-irradiation increases oxidative stress which alters the mitochondrial membrane integrity and releases the mitochondrial cytochrome-c into the cytosol, which increases the caspase- 3 activity and apoptosis (Verhagen et al., 2000; and Du et al., 2000), and results in large-scale fragmentation of DNA and condensation of chromatin (Susin et al., 1999 and Daugas et al., 2000). This finding is in agreement with the results obtained in the present study.

While in supplemented diet groups (with vit. C, vit. E and high protein concentration), there was an antiapoptotic activity compared to control and irradiated group. This antiapoptotic activity of vitamin $\mathrm{C}$ and vitamin $\mathrm{E}$ has been reported by several authors (Straface et al., 1995; Barroso et al., 1997; and Mobio et al., 2000).

The antiapoptotic activity of vitamins $\mathrm{C}$ and $\mathrm{E}$ may be attributed to reduce the activity of caspase 3 and maintain the Bcl-2 protein in its functional form by their membrane stabilizing action and thus inhibit the release of cytochrome-c from mitochondria. (Ramanathan et al., 2005; and Vijayalakshhmi, 2005).

Also, the antiapoptotic activity of high protein diet may be due to antioxidant activity of soybean protein supplementation diet, this finding is in agreement with Yerushalmi et al. (2001), and Abdullaev et al. (2002), they detected that soybean supplementation diet for old age rats has an antioxidant activity, thus reducing apoptosis by preventing the generation of oxidative stress which is a greater process occur by ageing per se and subsequent stimulation of the mitochondrial permeability transition and release of cytochrome-c from mitochondria which inhibit apoptosis process.

An ideal radioprotectant should offer significant protection against lethality from acute and long-term effects of radiation exposure; be suitable for oral administration and be rapidly absorbed and distributed throughout the 
body; cause insignificant toxicological effects, particularly those on behaviour; be readily available and affordable; and be chemically stable to permit easy handling and storage. Antioxidants are one such class of agents, which are nontoxic and moderately radioprotective which include vitamins $C$ and $E$ and soybean protein. it is quite possible that Vitamins $C$ and $E$ and high soybean protein supplementation diet provide protection from $\mathrm{Y}$-irradiation exposure at dose 7 Gy.

\section{REFERENCES}

Abdel-Gawad, I.I. and Amer, M.M. (2001). The protective effect of melatonin and vitamin $B_{6}$ against radiation in male rats. Arab. J. Lab. Med., 27(3): 289.

Abdel-Gawad, I.I.; Amer, M.M. and Nabarawy, S.K. (2003). Biochemical and hematological changes in female irradiated rats injected with selenium and/or vitamin E. Egypt. J. Appl. Sci., 18(9) : 11.

Abdullaev, Z.K.H.; Bodrova, M.E.; Cheryak, B.V.; Dolgikh, D.A.; Kluck, R.M.; Perererzev, M.O.; Arseniev, A.S.; Efremov, R.G.; Kirpichnikov, M.P.; Mokhova, E.N.; Newmeyer, D.D.; Roder, H. and Skulachev, V.P. (2002).

A cytochrome $\mathrm{C}$ mutant with high electron transfer and antioxidant activities but devoid of apoptogenic effect. Biochem. J., 362(3): 749 54.

Alici, B.M.K.; Gumustas, H.; Ozkara,E.; Akkus, G.; Demirel, F.Y. and Hattat, $H$. (2000). Apoptosis in the erectile tissue of diabetic and healthy rats. Bju International 85, 326-329. Istanbul, Turkey.

Anderson, J.W.; Smith, B.M. and Washnock, C.S. (1999). Cardiovascular and renal benefits of dry bean and soybean intake. Amer. J. Clin. Nutr. 70(3): $464 S-474 S$.

Aruoma, O.I. (1998). Free radicals, oxidative stress and antioxidants in human health and disease. J. Am. Chem. Soc., 75: 199.

Badr EL-Din, N.K. (2004). Influence of pretreatment with sanumgerman on total body $\mathrm{Y}$-irradiation induced kidney impairment in mice. Egypt. J. Rad. Sci. Applic., 17(1): 61.

Barlow, C., Brown, K., Deng, C., Tagle, D. and Wynshaw-Boris, A. (1997). ATM selectively regulates distinct p53-dependent cell-cycle checkpoints and apoptotic pathways. Nature Genetics 17, 453-456.

Barroso,M.P.; Diaz, C.G.; Lluch, G.L.; Malagon, M.M.; Crane, F.L. and Navas, P. (1997). Ascorbate and a222-tocopherol prevent apoptosis induced by serum removal independent of Bcl-2. Archiv. Biochem. Biophys., 343: $243-248$.

Cadenas, S. and Cadenas, A.M. (2002). Fighting the stranger antioxidants protection against endotoxin toxicology. Toxicology, 180: 45-63.

Cay, M. and Naziroglu, M. (1999). Effects of intraperitoneally administered vitamin $\mathrm{E}$ and selenium on the blood biochemical and haematological parameters in rats. Cell Biochem. Funct., 17(2): 143. 
Cook, J.G.H. (1975). Quantitative kinetic determination of Creatinine in serum.

Ann. Clin. Biochem., 12: 219.

Cui, Y.F.; Gao Y.B.; Yang, H.; Xiong, C.Q.; Xia, G.W. and Wang, D.W. Apoptosis of circulat-ing lymphocytes induced by whole body gammairradiation and its mechanism. J Environ Patho Toxicol Oncol (1999); 18(3):185-9.

Daugas, E.; Susin, S.A.; Zamzami, N.; Ferri, K.F.; Irinopoulou, T.; Larochette, N.; Prévost, M.C.; Leber, B.; Andrews, D.; Penninger, J. and Kroemer, G. (2000). Mitochondrio-nuclear translocation of AIF in apoptosis and necrosis.

FASEB J., 14: 729 - 739.

Du, C.; Fang, M.; Li, Y.; Li, L. and Wang, X. (2000). Amac, a mitochondrial protein that promotes cytochrome c-dependent caspase activation by eliminating IAP inhibition. Cell, 102: $33-42$.

El-Gabry, M.S.; Abou-Safi, H.; EL-Yamany, N. and Abdel-Hamid, G. (2003). Physiological studies on the efficacy of silymarin as antioxidant against the disorders in some blood constituents induced by irradiation in female rats. The Egyptian J. Hospital Medicine, 11: 1.

Fang, Y.Z. (1991). Effect of ionizing radiation on superoxide dismutase in vitro and in vivo. In: Advances in Free Radical Biology and Medicine (Fang, Y.Z. Ed.). Beijing, Atomic Energy Press, vol. 1: 1.

Farag, M.H. (1994). Upgrading whole someness of soybeans through radiation deactivation of toxic lectin content. Egypt. J. Rad. Sci. Applic., 7(1): 99.

Fawcett, J.K. and Scott, J.E. (1960). Enzymatic colorimetric test for urea. Clion. Path., 13: 156.

Geraci, J.P.; Jackson, K.L.; Mariano, M.S. and Michieli, B.M. (1990). Kidney and lung injury in irradiated rats protected from acute death by partial body shielding. Rad. Res., 112: 95.

Gobbel, G. T., Bellizona M., Vogt, A. R., Gupta, N., Fike, J. R. and Chan, P. H. (1998a). Response of postmitotic neurons to X-irradiation: Implication for the role of DNA damage in neuronal apoptosis. $J$. Neurosci. 18, 147-155.

Gougeon, M.L. and Montagnier, L. (1993).

Photometric enzyme-immunoassay for the qualitative and quantitative in vitro determination of cytoplasmic histone-associated-DNAfragments mono- and oligonucleosomes) after induced cell death. Science, 260: 1269.

Guido, K.; Patrice, P.; Neiouful, Z.; Jean, L.V. and Bernard, M. (1995). The Biochemistry of programmed cell death. J. 9: 1277-1287.

Haimovitz-Friedman, A. (1998). Radiation-induced signal transduction and stress response. Rad. Res. 150 (Suppl.), S102-S108.

Halliwell, B. and Gutteridge, J.C. (1995). The identification and measurement of antioxidants in biological systems. Free radic. Boil. Med., 18: $125-126$.

Hogg, N. (1998). Free radicals in disease. Semin. Reprod. Endocrinol., 16: 241-8. 
Ikeda, M.; Nakabayashi, K.; Shinkai, M.; Hara, Y.; Kizaki, T.; Oh-ishi, S. and Ohno, H. (2004). Supplementation of antioxidants prevents oxidative stress during a deep saturation dive. Tohoku J. Exp. Med., 203: 353357.

Jaime, M. (2002). Can antioxidant diet supplementation protect against agerelated mitochondrial damage? Ann. N. Y. Acad. Sci., 959: $508-516$.

Kanter, M.; Coskun, O.; Armutcu, F.; Uz, Y.H. and Kizilay, G. (2005). Tohoku J. Exp. Med., 206: 155 - 162.

Marton, Z.; Halmosi, R.; Horvath, B.; Alexy, T.; Kesmarky, G.; Vekasi, J.; Battyany, I.; Hideg, K. and Toth, K. (2001). Scavenger effect of experimental and clinically used cardiovascular drugs. J. Cardiovasc. Pharmacol., 38(5): 745-753.

Mobio, T.; Baudrimont, I.; Sanni, A.; Shier, T.W.; Saboureau, D.; Dano, S.D.; Udeno, Y.; Steyn, P.S. and Creppy, E.E. (2000). Prevention by vitamin $E$ of DNA fragmentation and apoptosis induced by fumonisin $B_{1}$ in C6 glioma cells. Archiv. Toxicol., 74: 112 -p 119.

Monig, H.; Messerschmidt, O. and Streffer, C. (1990). Chemical radioprotection in mammals and in man. In: Radiation Exposure and Occupational Risks (Scherer, E.; Streffer, C. and Trott, K.R. Eds.). Berlin, Springer-Verlag, pp. 97-143.

Morita, T.; Oh-hashi, A.; Takei, K.; Ikai, M. and Kasaoka, S. (1997). Cholesterol lowering effects of soybean, potato and rice proteins depend on their low methionine contents in rats fed a cholesterol free purified diet. J. Nutr. 127: $470-477$.

Murray, R.K.; Granner, D.K.; Mayes, P.A. and Rodwell, V.W. (1993). Harper's Biochemistry, twenty-third edition, Appleton and Lange, Librairie du Liban.

Olas, B. and Wachowicz, B. (2002). Resveratol and vitamin C as antioxidant in blood platelets. Thromb. Res., 106: $143-148$.

Packer, L. (1991). Protective role of vitamin E in biological systems. Am. J. Clin. Nutr., 53: 1050-1055.

Ramadan, L.; Shouman, S.; Sayed, M. and EL-Habit, O. (2001). Modulation of radiation-induced organs toxicity by cremophor-el in experimental animals.

Pharmacol. Res., 43(2) : 185.

Ramanathan, K.; Anusuyadevi, M.; Shila, S. and Panneerselvam, C. (2005). Ascorbic acid and alpha-tocopherol as potent modulators of apoptosis on arsenic induced toxicity in rats. Toxicol. Lett. 156(2): 297-306.

Souba, W.W. and Wilmore, D.W. (1983). Postoperative alteration of arteriovenous exchange of amino acids across the gastrointestinal tract. Surgery, 94: $342-350$.

Straface, E.; Santini, M.T.; Donelli, G.; Giacomoni, P.U. and Malorni, W. (1995). Vitamin E prevents UVB-induced cell blebbing and cell death in A431 epidermoid cells. Int. J. Radiat. Boil., 68: $579-587$.

Susin, S.A.; Lorenzo, H.K.; Zamzami, N.; Marzo, I.; Snow, B.E.; Brothers, G.M.; Mangion, J.; Jacotot, E.; Costantini, P.; Loeffler, M.; Larochette, N.; Goodlett, D.R,; Aebersold, R.; Siderovski, D.P.; Penninger, J.M. 


\section{Shallan, A.M. et al.}

and Kroemer, G. (1999). Molecular characterization of mitochondrial apoptosis-inducing factor. Nature, 397: $441-446$.

Szumiel, I. (1994). Review: lonizing radiation-induced cell death. Int. J. Rad. Biol. 66, 329-341.

Szumiel, I. (1998). Monitoring and signaling of radiation-induced damage in mammalian cells. Rad. Res. 150 (Suppl.), S92-S101.

Tchell, H.S.M.I.; Effrey, M.E.J.; Jorden, D.; Tobin, J.P.; Mar, C.R. and Black, M. (2001). Longitudinal effect of aging on serum total and free testosterone on levels in healthy men. Journal of clinical Endocrinology and Metabolism, 86: 724-731.

Thefeld, W. (1974). Kinetic determination of alanine and aspartate aminotransferase activity. Dtsch. Med. Wschr., 99: $343-351$.

Verhagen, A.M.; Ekert, P.G.; Pakusch, M.; Silke, J.; Connolly, L.M.; Reid, G.E.; Moritz, R.L.; Simpson, R.J. and Vaux, D.L. (2000). Identification of DIABLO, a mammalian protein that promotes apoptosis by binding to and antagonizing IAP proteins. Cell, 102: $43-53$.

Vijayalakshhmi, B.; Sesikeran, B.; Udaykumar, P.; Kalyanasundaram, S. and Raghunath, M. (2005). Effects of vitamin restriction and supplementation on rat intestinal epithelial cell apoptosis. Free Radical Biol. Med. 38(12): 1614-24.

Yan, L.Z.; Hermann, V.; Hofor, J.K. and Insol, P.A. (2000). B-adrenergic receptor (AMP-mediated) signaling and apoptosis of S49 lymphoma cells. Am. J. physiol. Cell physiol., 279:C1665-C1674.

Yanagihara, K.; Nii, M.; Numoto, M.; Kamiya, K.; Tauchi, H.; Sawada, S.and Seito, T. (1995). Radiation-induced cell death in human gastric epithelial tumour cells; correlation between mitotic death and apoptosis. IntJ. Rad. Biol. 67, 677-685.

Yanardag, R.; Bolkent, S. and Kizir, A. (2001). Protective effects of DLalpha-tochopherol acetate and sodium selenate on the liver of rats exposed to gamma radiation. Boil. Trace Elem. Res., 83(3): 263.

Yerushalmi, B.; Dahl, R.; Devereaux, M.W.; Gumpricht, E. and Sokoi, R.J. (2001). Bile acid induced rat hepatocyte apoptosis is inhibited by antioxidants and blockers of the mitochondrial permeability transition. Hepatology, 33(3): $616-26$. 


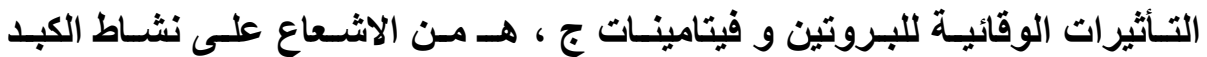

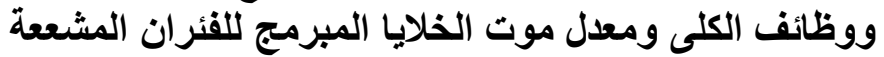

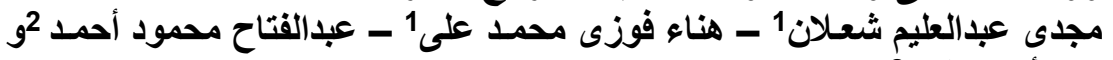
منى أحمد غنيم2 2 1 قسم الكيمياء الحيوية ـ كلية الزراعة ـ ـامعة القاهرة. 2 قسم النظائر المشعةية ـ- هيئة الطاقة الذرية.

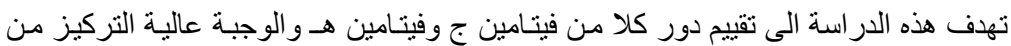

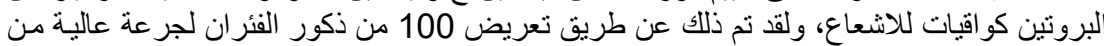

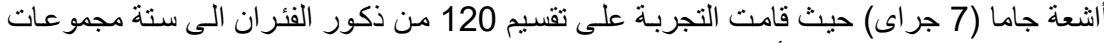
تحوى كل مجمو عة عشرون فأرا على النحو التالى: - مجمو عة ضابطة.

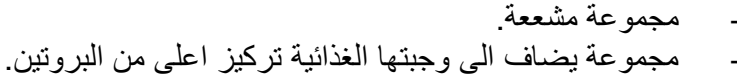

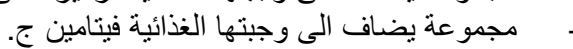

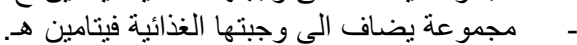

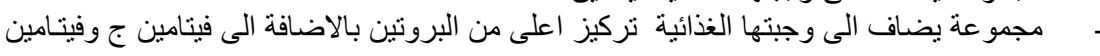

تم تقدير نثاط انزيمى الألانين أمينو ترانس فيريز (ALT) و والأسبر اتات أمينو ترانس فيريز

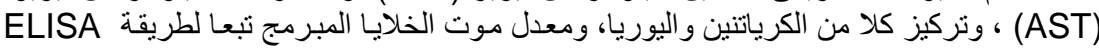

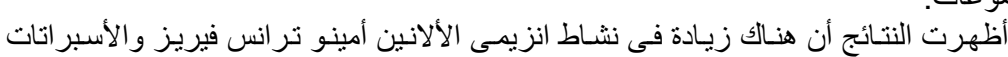

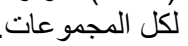

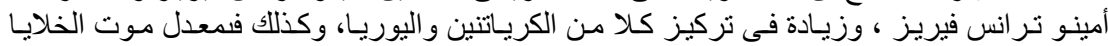

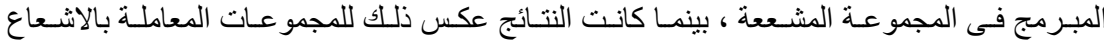
وامغذيات المختلفة.

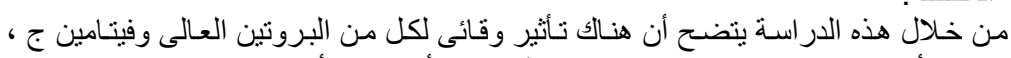

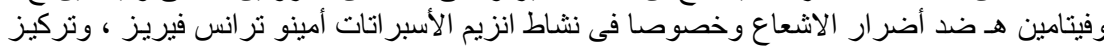
الكرياتتين ومعدل موت الخلايا المبرمج. 